\title{
Bankowość w wykładach Juliana Dunajewskiego
}

\section{Przemysław Rapka}

Uniwersytet Ekonomiczny w Katowicach, Wydział Ekonomii, przemyslaw.rapka@edu.uekat.pl, ORCID: 0000-0003-3532-6417

Streszczenie: Julian Dunajewski był polskim ekonomistą i ministrem skarbu Austro-Węgier w drugiej połowie XIX w. Wykładał również na Uniwersytecie Jagiellońskim w Krakowie oraz na Uniwersytecie Lwowskim. Niestety pisał niewiele i jego myśl ekonomiczna jest znana głównie ze skryptów z lat 70. XIX w. Zawarte są w nich m.in. omówienie kwestii funkcjonowania banków i sektora bankowego, a także przemyślenia Dunajewskiego o konsekwencjach gospodarczych funkcjonowania nieregulowanego sektora bankowego, gdzie banki mogą dowolnie emitować banknoty. W tekście przedstawiono i przeanalizowano poglądy Juliana Dunajewskiego dotyczące funkcjonowania sektora bankowego oraz skutków braku regulacji kreacji pieniądza bankowego. Dunajewski twierdził, że nieuregulowana kreacja pieniądza przez banki komercyjne jest przyczyną cykli koniunkturalnych i spadku wartości pieniądza. Jego poglądy na wolną bankowość zostały porównane $\mathrm{z}$ poglądami współczesnych zwolenników wolnej bankowości oraz ekonomistów szkoły austriackiej. Analiza porównawcza ukazuje podobieństwa poglądów ekonomistów szkoły austriackiej i Juliana Dunajewskiego na konsekwencje emisji pieniądza przez banki komercyjne. Zarówno według szkoły austriackiej, jak i Dunajewskego nadmierny kredyt bankowy odpowiada za cykle koniunkturalne oraz udzielanie kredytu niewłaściwym przedsiębiorcom.

Słowa kluczowe: Julian Dunajewski, wolna bankowość, polska myśl ekonomiczna, szkoła austriacka.

Kod JEL: B19, B26, G21.

\section{Wstęp}

Julian Dunajewski był polskim ekonomistą, zapamiętanym przede wszystkim jako minister skarbu w monarchii Austro-Węgier w latach 1880-1891. W trakcie pełnienia tej funkcji przeprowadził reformy skarbowe, dzięki którym udało się wyeliminować deficyt budżetowy (Olejnik, 2017). Oprócz tego Dunajewski był 
również wykładowcą akademickim związanym z Uniwersytetem Jagiellońskim w Krakowie oraz przez pewien czas z Uniwersytetem Lwowskim. Na uczelniach prowadził wykłady z ekonomii politycznej, skarbowości, statystyki (rozumianej nie jako analiza danych liczbowych, a wiedza o demografii i geografii ekonomicznej) i prawa administracyjnego.

Niestety Dunajewski nie napisał wielu prac. Za życia wydał: Ziemię i kredyt, Stowo o Kopernika zasadach bicia monety oraz - wspólnie z Wiktorem Kopffem i Dionizym Skarżyńskim - Zarys organizacyi władz administracyjnych dla Galicji. Poglądy ekonomiczne Dunajewskiego są znane dzięki skryptowi spisanemu przez jednego z jego studentów (Koniarek, 2014). To właśnie na tym skrypcie (Dunajewski, 2012), który pochodzi z lat 1872-1873, opiera się niniejszy artykuł.

Dunajewski był zwolennikiem liberalizmu - Ferdynand Zweig scharakteryzował jego poglądy w następujący sposób: „Wierzył zasadniczo w istnienie niezmiennych praw naturalnych, które stwarzają harmonię interesów i równowagę sił ekonomicznych. Jest niestrudzonym w zalecaniu wolności we wszystkich dziedzinach życia, jako panaceum na wszelkie dolegliwości gospodarcze" (Szulczewski, 2019, s. 293). Dunajewski nie był jednak skrajnym liberałem, ponieważ uważał, że państwo ma do odegrania większą rolę w społeczeństwie, niż tylko rolę stróża nocnego.

Chociaż był on zwolennikiem wolności i gospodarki rynkowej, to potrafił spojrzeć krytycznie na konkurencję. W swoim wykładzie o bankowości Dunajewski twierdził, że konkurencja między bankami, których działalność nie jest uregulowana, może mieć negatywne skutki gospodarcze, takie jak problem wspólnego pastwiska (nazwa ta została nadana później). Istnienie tego problemu implikuje dwie kolejne kwestie: cykl koniunkturalny oraz negatywny wpływ konkurencji między bankami na wartość środków obiegowych ${ }^{1}$.

Niniejszy artykuł to praca z zakresu historii myśli ekonomicznej, w którym analizowana jest teoria bankowości Juliana Dunajewskiego, przedstawiona w $W y$ kładach ekonomii politycznej (Dunajewski, 2012). Głównym celem artykułu jest prezentacja poglądów Juliana Dunajewskiego (2012) dotyczących bankowości oraz porównanie ich z poglądami współczesnych zwolenników wolnej bankowości oraz szkoły austriackiej na funkcjonowanie systemu bankowego. Natomiast z poglądami ekonomistów szkoły austriackiej zestawiono poglądy Dunajewskiego na temat skutków kreacji pieniądza przez banki komercyjne.

1 Według terminologii Dunajewskiego środki obiegowe to inaczej pieniądz i jego substytuty monety zdawkowe czy niektóre rodzaje papierów wartościowych, np. weksle i banknoty. Omówienie zagadnienia pieniądza i jego substytutów znajduje się w pracy Misesa (2012). 
W opracowaniu wykorzystano analizę porównawczą, rozpatrując równolegle i porównując w kolejnych częściach pracy poglądy Dunajewskiego z poglądami zwolenników wolnej bankowości oraz ekonomistów szkoły austriackiej. Punkt 2 artykułu przedstawia opis biznesu bankowego, jaki Dunajewski zawarł w $W y$ kładach ekonomii politycznej (2012). W punkcie 3 zaprezentowano omówienie wolnej bankowości przez Dunajewskiego i współczesnych zwolenników wolnej bankowości. W punktach 4 i 5 dokonano analizy problemów, które według Dunajewskiego wynikają z nieregulowanej konkurencji między bankami komercyjnymi - cyklu koniunkturalnego, inflacji i problemu wspólnego pastwiska.

\section{Funkcje banków i środków obiegowych}

Opis funkcjonowania bankowości u Dunajewskiego nie jest zaskakujący. Stwierdził on: „Bank jest to więc przedsiębiorstwo, którego zadaniem jest handlować bądź gotówką, bądź kredytem (dziś przeważnie kredytem)" (Dunajewski, 2012, s. 129), w którym składane są depozyty, a następnie bank udziela dzięki nim kredytu innym przedsiębiorcom. Bank dba przy tym, by zawsze trzymać odpowiednie rezerwy, aby móc spłacić zobowiązania. „Przede wszystkim trzeba zwrócić uwagę na to, że w każdym przedsiębiorstwie, gdzie tylko jaki taki podział pracy istnieje, trzeba zawsze pewną większą lub mniejszą cząstkę kapitału posiadać w gotówce, bo w każdym przedsiębiorstwie przychód i rozchód jest czasowo rozbieżny. Otóż pewna cząstka kapitału musi być umieszczona w formie pieniężnej, aby przedsiębiorstwo w każdej chwili mogło stawić czoło żądaniom zapłaty z jakiegokolwiek tytułu prawnego" (Dunajewski, 2012, s. 129).

Do głównych operacji banku należą:

1. Ocena ryzykowności przedsięwzięcia (Dunajewski, 2012, s. 130) - ryzyko według Dunajewskiego stanowi istotny element oprocentowania transakcji, obok kosztów amortyzacji kapitału (Dunajewski, 2012, s. 175).

2. Pośrednictwo w obrocie wekslami. „Co się tyczy weksli, to bank pośredniczy w obiegu tych weksli w sposób bardzo prosty. Jeżeli rolnik bierze maszynę od fabrykanta i powiada: proszę na moje imię weksel wystawić, zachodzi trudność, że może by mu hurtownik nie przyjął tego weksla, więc tu pośredniczy bank, bankier dyskontuje ten weksel, nabywa dla siebie, a wydaje pieniądze, które są bądź własne, bądź klientów, którzy je u niego złożyli” (Dunajewski, 2012, s. 130).

3. Przekazywanie pieniędzy między krajami lub regionami, dzięki związkom między sobą (Dunajewski, 2012, s. 130). 
Dunajewski poświęcił dodatkowo nieco uwagi środkom obiegowym, czyli instrumentom denominowanym we właściwym pieniądzu. Środki te mogą być wykorzystane jako bardzo bliski substytut pieniądza. Należą do nich już wspomniane weksle oraz bilety bankowe, czyli po prostu banknoty. Banknoty to, według Dunajewskiego (2012, s. 132-133), „weksel bankowy, wystawiony przez bank na siebie, płatny w każdej chwili okazicielowi. Taki bilet zastępuje więc właściwie gotówkę". Są one wprowadzane do obiegu w trakcie udzielania kredytu. „Wydaje te bilety bank przy sposobności załatwiania swoich interesów bankierskich. Dajmy na to, że nasz rolnik chciałby kupić żelaza, ale nie ma gotówki, zgłasza się więc do banku biletowego i powiada: Oto macie weksel np. na 1000 zł płatny za 3 miesiące, chciałbym kupić za te pieniądze żelaza. Bank potrąca dyskont za te trzy miesiące i płaci w swych biletach bankowych" (Dunajewski, 2012, s. 132).

Bank musi jednak dbać o swoją opinię. Jeśli ludzie nie będą wierzyć w to, że bank jest w stanie regulować swoje zobowiązania, to emitowane przez niego banknoty nie będą wyceniane zgodnie z ich nominałem. W związku z tym bank musi utrzymywać odpowiednio duże rezerwy, aby nigdy nie miał problemu wypłacić kruszcu monetarnego na żądanie (Dunajewski, 2012, s. 134).

Dunajewski przedstawił standardowy opis bankowości funkcjonującej na podstawie rezerwy cząstkowej, gdzie banki emitujące banknoty kreują pieniądz. Gromadzone jest złoto i srebro, czyli właściwe pieniądze, które następnie banki wykorzystują jako rezerwy dla ekspansji kredytowej, czyli udzielania kredytu $\mathrm{w}$ postaci swoich banknotów. Te rezerwy mogą również być pożyczone w ramach kredytu lub dyskontowania weksla.

Omawiając kredyt, Dunajewski zgadzał się z definicją Augusta Cieszkowskiego, którego poglądy omawiał w Wyktadach ekonomii politycznej. Cieszkowski stwierdzał, że kredyt to operacja mająca na celu „uruchomienie” kapitału, czyli po prostu sfinansowanie wykorzystania kapitału w działalności gospodarczej. „Kapitał już użyty w produkcji jest czynny, zaś nieużyty jeszcze, ale mogący być użyty, jest kapitałem martwym" - stwierdzał Dunajewski (2012, s. 116). Wskazywał jednak na to, że nie trzeba zaciągać kredytu, aby zaangażować kapitał w produkcję; wystarczy posiadać pieniądze. Dlatego dodawał, że, wyłączając przypadki zaciągania kredytu na potrzeby konsumpcji, „Trzeba było więc dać definicję taką: »kredyt jest to zamiana kapitałów martwych na czynne « z dodatkiem: bez pośrednictwa gotowych pieniędzy” (Dunajewski, 2012, s. 117). 


\section{Wolna bankowość według Dunajewskiego i współczesnych ekonomistów}

Po omówieniu funkcjonowania banków Dunajewski zajął się problemem organizacji sektora bankowego, zastanawiając się, czy wolna bankowość jest optymalnym systemem monetarnym, czy też może konkurencja między bankami może mieć negatywne skutki. Głównym problemem jest emisja banknotów przez banki, które sprowadza się do pytania, czy wszystkie banki powinny mieć prawo dowolnie emitować banknoty, czy też emisja ta powinna być regulowana przez państwo.

Wolna bankowość współcześnie oznacza brak regulacji sektora bankowego pod jakimkolwiek względem. Sechrest $(2008$, s. 3) za najważniejsze cechy wolnej bankowości uznaje:

a) brak państwowych barier wejścia i wyjścia,

b) brak ograniczeń emisji banknotów i depozytów przez banki,

c) brak banku centralnego,

d) brak państwowych gwarancji depozytów,

e) brak regulacji rezerw banków,

f) brak minimalnych wymogów kapitałowych,

g) brak ograniczeń działalności banków, takich jak ograniczenie ich możliwości inwestowania w akcje i obligacje,

h) brak kontroli stóp procentowych; wolna bankowość ma być całkowitą deregulacją sektora bankowego i oznacza wprowadzenie radykalnego leseferyzmu w sektorze finansowym.

Omawiając wolną bankowość, Dunajewski zestawił ze sobą dwie formy funkcjonowania bankowości - monopol pieniężny i wolną bankowość. Monopol pieniężny oznacza, że tylko jeden bank w kraju ma koncesję na emisję banknotów (Dunajewski, 2012, s. 13). Nie analizuje on w takich szczegółach wolnej bankowości, jak współcześni zwolennicy tego modelu bankowości. Dunajewski nie pisze obszernie o mechanizmach, które miałyby zapewniać stabilność lub destabilizować sektor bankowy. Przedstawia on powszechną obronę wolnej bankowości, argumenty przeciw wolnej bankowości oraz jej własną krytykę wolnej bankowości.

Argument ówczesnych zwolenników wolnej bankowości, według Dunajewskiego, sprowadza się do pochwały konkurencji. „Zysk społeczny płynący z banku zasadza się głównie na tym, aby wszystkie te czynności, które bank załatwia, spełniał przy najniższych kosztach, aby ułatwiał pożyczki wekslowe, ułatwiał 
pożyczki na zastaw, ułatwiał cały obieg pieniężny kraju po cenie umiarkowanej, którą bank pobiera za swe usługi od osób z nim w styczności będących. Jeżeli zaś jest bank monopolistyczny, to trudno spodziewać się, aby ta cena była umiarkowaną. Trzeba pozwolić, aby było więcej banków, a jeżeli nie będzie potrzeba tylu banków, to się nie utrzymają, a korzyść mamy tę, że bank, ciągnąć publiczność do siebie, zniżać będzie cenę. Tym sposobem przedsiębiorstwo banków biletowych może pracować z korzyścią dla siebie i dla publiczności. Udzielać komuś przywilej, aby tylko on jeden mógł wystawiać podobne bilety, znaczy odejmować innym prawo powszechne, prawo wszystkim ostatecznie obywatelom służące” (Dunajewski, 2012, s. 138). „Jeżeli konkurencja wolna wszędzie jest przyjętą, dlaczegóż właśnie w przedsiębiorstwie bankowym ma ona być szkodliwą?" (Dunajewski, 2012, s. 141).

Dunajewski podaje, że ówcześni zwolennicy wolnej bankowości zwracają również uwagę na to, że „każdy prywatny obywatel możny jest wystawiać jakiekolwiek znaki kredytowe; czy np. podpiszę weksel, czy zwykły skrypt długu wystawię, zawsze to na jedno wychodzi. Zwłaszcza w przedsiębiorstwach większych, bez kredytu nie może być mowy o prawidłowym prowadzeniu przedsiębiorstwa. W takich wypadkach, gdzie rozwój handlu zmusza do powiększenia przedsiębiorstwa, droga kredytu jest prawidłowo główną drogą, za pomocą której można zasilać przedsiębiorstwo. Jeżeli każdemu wolno używać swego kredytu dowolnie i za to odpowiada przed sądem, skądże ustawodawca przychodzi do tego ograniczenia wolności wszystkim służącej pod względem przedsiębiorstwa bankowego?" (Dunajewski, 2012, s. 141).

Konkurencja między bankami emitującymi banknoty ma zapewnić, według zwolenników wolnej bankowości, tani i elastyczny obieg pieniądza, który usprawnia gospodarkę oraz ułatwi dostęp do kredytu. Sama konkurencja ma zapewnić również odpowiednią liczbę banków i banknotów w obiegu.

Po przytoczeniu argumentu za wolną bankowością Dunajewski przedstawia krytykę prezentowaną przez współczesnych mu ekonomistów, z którą się nie zgadza, a następnie własną krytykę.

Powszechna krytyka wolnej bankowości, na którą odpowiada Dunajewski, głosi, że tylko państwo powinno emitować banknoty, ponieważ banknot ma być substytutem kruszcu, oraz że zadaniem władzy jest dbanie o wartość pieniądza, i tylko państwu przysługuje prawo bicia monety (Dunajewski, 2012, s. 138). Według Dunajewskiego to nie jest trafna krytyka, ponieważ banknot emitowany przez państwo jest inny od banknotu emitowanego przez bank. Wynika to z faktu, że państwo emitując banknoty, emituje własny dług: „Rozumie się, że rząd 
wtenczas, kiedy wydał tę notę, nie miał pieniędzy, ale miał nadzieję, że może za rok fundusze się pomnożą. Ta nota więc (waluta papierowa) reprezentuje wartości rzeczowe, które dopiero mają powstać (...). Jest to dług państwa. Bilet bankowy, w zwykłym toku rzeczy, jest przez bank emitowany w zamian za weksel towarowy, wystawiony przez przemysłowca lub kupca celem uiszczenia $\mathrm{w}$ ten sposób należytości za towar (...). Takie weksle są więc reprezentantami wartości rzeczowych (...). To jest pierwsza zasadnicza różnica między walutą papierową a biletem bankowym" (Dunajewski, 2012, s. 139).

Dunajewski zwraca również uwagę na różnice w kontrolowaniu ilości pieniądza w obiegu. W przypadku waluty papierowej (banknotów rządowych) ich ilość jest regulowana zarówno wielkością wydatków państwowych, jak i wielkością podatków. Jeżeli pieniądza jest za wiele i ,jest przyczyną zachwiania stosunków handlowych całego kraju", wtedy rząd podnosi podatki. Jednak nie zawsze jest w stanie ściągnąć ich odpowiednią ilość (Dunajewski, 2012, s. 140). Tymczasem w przypadku banknotów emitowanych przez banki, ich ilość jest regulowana w sposób ciągły. Po pierwsze, banknoty są wycofywane z obiegu, gdy ktoś wypłaca złoto lub srebro. Po drugie, banknot znika z obiegu, gdy spłacany jest dług. Banknoty są wydawane na podstawie weksli i gdy weksle są spłacane, to pieniądz jest wycofywany z obiegu (Dunajewski, 2012, s. 140-141).

$\mathrm{Z}$ tych dwóch powodów Dunajewski odrzuca pogląd ówczesnych przeciwników wolnej bankowości (emisji banknotów przez banki komercyjne). „Tak więc argument obrońców monopolu bankowego przytaczany, że dlatego musi być monopol, bo banknot jest znakiem pieniężnym tak jak każdy inny, teoretycznie usprawiedliwić się nie da" (Dunajewski, 2012, s. 141). Nie oznacza to, że Dunajewski był zwolennikiem wolnej bankowości, za jaką opowiadają się jej współcześni zwolennicy. Dunajewski twierdził, że konkurencja między nieregulowanymi bankami ma negatywne skutki. Natomiast współcześni zwolennicy wolnej bankowości przedstawiają opis funkcjonowania nieregulowanego sektora bankowego, który ma dowodzić, że wolna bankowość jest optymalnym systemem bankowym.

Argument współczesnych zwolenników wolnej bankowości za brakiem regulacji okazuje się, co do jego istoty, taki sam, jak argument zwolenników - skoro konkurencja sprawdza się we wszystkich innych sektorach gospodarki, to dlaczego ma się nie sprawdzić w sektorze bankowym (Dowd, 1996).

Współcześni zwolennicy wolnej bankowości uważają, że nie powinien istnieć bank centralny, a państwo nie powinno regulować w żaden sposób kreacji kredytu, ekspozycji na ryzyko czy struktury kapitału banków (Glasner, 1989; 
Sechrest, 2008). Sam system monetarny miałby być oparty na standardzie złota. Złoto jest wykorzystywane jako pieniądz, a banknoty są wymienialne na żądanie u emitenta banknotu (Dowd, 1993; Selgin, 2017). Konkurencja między bankami miałaby zapewniać stabilność sektora finansowego, odpowiednią elastyczność waluty, a także należycie regulować wysokość stóp procentowych.

Podobnie jak Dunajewski w swoim wykładzie, tak samo współcześni autorzy zwracają uwagę na to, że banki w systemie wolnej bankowości muszą zarządzać swoimi rezerwami. Na podstawie przewidywanej wielkości odpływu rezerw banki będą odpowiednio zwiększać lub zmniejszać swój stosunek udzielonego kredytu do trzymanych rezerw oraz będą dostosowywać oprocentowanie kredytu i depozytów. Spodziewając się spadku popytu na pieniądz (czyli spadku części dochodów utrzymywanych na saldach gotówkowych przez ludzi w danym okresie), bank będzie ograniczał emisję kredytu. Natomiast wzrost popytu na pieniądz będzie prowadził do wzrostu emisji kredytu przez banki, ponieważ dzięki zwiększonemu popytowi na pieniądz banki dysponują teraz większymi rezerwami, na podstawie których mogą udzielać kredytu (Selgin, 1989, s. 64-69).

Sektor bankowy, według zwolenników wolnej bankowości, działa stabilizująco na gospodarkę, ponieważ stabilizuje on strumień wydatków w gospodarce. Gdy rośnie popyt na pieniądz, banki komercyjne mogą wyemitować dodatkowy pieniądz, dzięki czemu gospodarka uniknie sytuacji niepełnego wykorzystania zasobów. Natomiast spadek popytu na pieniądz (ze strony ludzi lub banków) sprawi, że banki ograniczą kreację kredytu, zmniejszając w ten sposób konkurencję o zasoby i nie dopuszczając do nadmiernego, niemożliwego do podtrzymania, ożywienia gospodarczego (Selgin, 2017, s. 5-7).

Wolna bankowość według jej zwolenników ma zapewnić również odpowiedni poziom stóp procentowych. Sam mechanizm regulacji stóp procentowych jest całkiem prosty. Banki z jednej strony starają się pozyskać depozyty, z drugiej strony - kredytobiorców, i muszą dostosowywać swoje stopy procentowe do preferencji potencjalnych depozytariuszy i kredytobiorców. W przypadku depozytów banki chcące rozszerzyć swoją ekspansję kredytową musiałyby zaoferować wyższe oprocentowanie depozytów. Podobnie pojedynczy bank musiałby zaoferować wyższą stopę procentową, gdy chce uniknąc nadmiernego odpływu depozytów złożonych przez ludzi. Jeśli spada popyt na pieniądz, bank musi zaoferować wyższe oprocentowanie rachunków właścicielom depozytów, by przyciągnąc dodatkowe rezerwy albo ograniczyć ekspansję kredytową. Spadek popytu na pieniądz prowadzi do spadku rezerw banków, co zmusza banki do podniesienia stóp procentowych - ograniczenia kreacji kredytu, przez co wzrośnie opro- 
centowanie kredytu oraz depozytów, ponieważ banki będą starały się zatrzymać odpływ rezerw. Działa to również w drugą stronę, czyli w przypadku wzrostu popytu na pieniądz banki komercyjne już nie muszą utrzymywać aż tak wysokich rezerw bankowych, co pozwala im zaoferować niższe oprocentowanie depozytów i wyemitować tańszy kredyt (Glasner, 1989, s. 17-18).

Jednak Dunajewski jest krytyczny wobec wolnej bankowości, z powodu wpływu, jaki wywiera nieregulowana emisja banknotów na funkcjonowanie gospodarki. Zwraca uwagę, że jest różnica między prowadzeniem banku a emisją banknotów. Można prowadzić bank - gromadzić depozyty, dyskontować weksle, udzielać kredytu - bez emitowania banknotów (Dunajewski, 2012, s. 142). Sama konkurencja między bankami, których możliwość emisji banknotów jest nieregulowana, ma dwie główne konsekwencje - cykle koniunkturalne i wartość środków obiegowych. Dunajewski twierdzi, że pogoń za klientem i zyskiem ma prowadzić do sytuacji, gdy stopy procentowe będą zaniżone, a rezerwy nieuregulowanych banków komercyjnych zostaną szybko wydrenowane na skutek nadmiernej emisji banknotów przez banki komercyjne. Pogląd Dunajewskiego jest sprzeczny z poglądami współczesnych zwolenników wolnej bankowości konkurencja między bankami kreującymi pieniądz wcale nie jest optymalnym systemem bankowym (Dunajewski, 2021, s. 143-144).

\section{Cykle koniunkturalne}

Omawiając bankowość, Julian Dunajewski poruszył krótko problem cykli koniunkturalnych, które stanowią jedno z dwóch następstw tragedii wspólnego pastwiska. Według Dunajewskiego cykle koniunkturalne są negatywnym skutkiem konkurencji między bankami komercyjnymi, które konkurują o klienta, oferując coraz tańszy kredyt. Co więcej, ta teoria cykli wyróżnia się na tle innych teorii cykli, znanych w ówczesnych czasach, ponieważ Dunajewski w paru akapitach zwracał uwagę na błędne inwestycje, ryzyko i nadmierny optymizm.

Dunajewski (2012, s. 143) podkreślał, że zbyt duża konkurencja między bankami skutkuje zaniżeniem stopy procentowej: „Ale ponieważ my tu przypuszczamy konkurencję żywą, gorącą, to gdzie ona znajdzie swój wyraz? Oto znajdzie swój wyraz w stopie dyskonta. Więc będą współzawodniczyć banki te w stopie procentowej, która być może z $7 \%$ zejdzie na $4 \%$, bywało $2 \% \mathrm{w} \mathrm{Za-}$ chodniej Europie". Jednak ta obniżka stóp procentowych wcale nie musi być korzystna. Podstawą tworzenia kapitału jest inwestowanie oszczędności (Dunajewski, 2012, s. 63-65). To inwestowanie w tworzenie kapitału wymaga zachęty 
w formie odpowiednio wysokiej stopy procentowej. Zbyt niska stopa nie pozwoli odtworzyć kapitału, a przez to spowolni proces akumulacji kapitału (Dunajewski, 2012, s. 175-176).

W następstwie emisji banknotów przez system bankowy nie powstaje nowy kapitał, stanowiący źródło finansowania oszczędności, a kreowany jest wyłącznie kredyt przez banki. „Ale zwróćmy w przód uwagę, jakiego to rodzaju jest kapitał, o którym mówimy? Rozumie się, że to tylko kredyt, czyli zaufanie. Np. sprowadziłem towar z zagranicy na podstawie biletów, które bank dał, a dał on dyskontując weksle; nie dał więc bank kapitału, tylko zaufanie" (Dunajewski, 2012, s. 143).

Kreacja pieniądza i zaniżenie stopy procentowej sprawiają, że banki muszą starać się o coraz większą liczbę klientów. Prowadzi to do tego, że banki zaczynają udzielać większej ilości kredytu oraz finansować większą liczbę przedsięwzięć. Łatwa dostępność pieniądza prowadzi do tego, że ludzie chętniej zwracają się do banków po kredyt, aby sfinansować nowe przedsięwzięcia, przez co „powstaje gorączkowość w zakładaniu przedsiębiorstw, która nie może być inaczej nazwana, jako chorobą ekonomiczną" (Dunajewski, 2012, s. 144). Nadmierna emisja pieniądza przez banki prowadzi więc do boomu gospodarczego, który zakończy się kryzysem.

Warto zwrócić uwagę, że teorię Dunajewskiego można zaklasyfikować jako monetarną teorię cyklu koniunkturalnego. To czynniki monetarne odpowiadają za rozpoczęcie cyklu, a nie zmiany w urodzaju, technologii czy niewystarczający popyt. To zmiany w sferze monetarnej odpowiadają za nadmierne ożywienie gospodarcze, które kończy się kryzysem (Hayek, 2014).

W następstwie kreacji pieniądza przez banki finansowane powstaje wiele nowych firm, które ostatecznie okażą się nierentowne. „Oto to, że w tej liczbie przedsiębiorstw, powstających wskutek ułatwiania dyskontowania weksli, jest bardzo wiele takich, które nie przynoszą skutków spodziewanych" (Dunajewski, 2012, s. 144). Dunajewski zwraca uwagę, że wiele przedsięwzięć okaże się ostatecznie nierentownych, ponieważ tym nowym przedsiębiorcom nie zależy na tym, by o firmę zadbać, ale żeby ją sprzedać (Dunajewski, 2012, s. 144).

Zakładaniu nowych przedsiębiorstw towarzyszy nadmierny optymizm na rynku. Kiedy powstają nowe firmy, dodatkowym przedsiębiorcom, którzy zostali sfinansowani dzięki zaniżeniu stopy procentowej, „nie idzie o przedsiębiorstwo, tylko o te pierwsze wielkie nadzieje, które zbierają w gospodarstwie. Chodzi im tylko o to, ażeby nowo założone przedsiębiorstwo z korzyścią sprzedać; co się potem stanie z przedsiębiorstwem, tego się nie mówi; niech się o to ci troszczą, w których ręku zostanie ostatecznie to przedsiębiorstwo" (Dunajewski, 
2012, s. 144). Dochodzi do wybuchu nadmiernego optymizmu, który prowadzi do zbyt pozytywnego oceniania przyszłości przedsiębiorstwa i jego nadmiernej wyceny. Sprzyja temu tworzenie narracji, głoszącej świetlaną przyszłość firmy. „Taka jest natura ludzka: ogłasza się szumne zapowiedzi. Trzeba starać się o kilka imion powszechnie znanych; nadto dziennikarstwo popiera i zachwala" (Dunajewski, 2012, s. 144).

W końcu dochodzi do kryzysu. Zanim jednak to nastąpi, powstają kolejne banki, które chcą zarobić na zwiększonym popycie na kredyt i emisji banknotów. Można doszukiwać się tutaj pewnego procesu kumulacyjnego, gdzie boom i zyski skłaniają do zakładania kolejnych banków emitujących banknoty: „Otóż ta chęć zbogacenia się, ta łatwowierność w przyjmowaniu wiadomości o przyszłych zyskach, popiera także zakładanie banków” (Dunajewski, 2012, s. 144).

Jednak w końcu dochodzi do załamania, ponieważ kolejne przedsiębiorstwa będą upadać - ich plany były błędne i z tego powodu stały się nierentowne. Z powodu tej nierentowności kredyty banków nie są spłacane. Banki zaczynają podnosić stopy procentowe, co wywołuje panikę na giełdzie. „Prędzej lub później po każdej takiej epoce przychodzi do katastrofy. Jedno, drugie, trzecie przedsiębiorstwo nie tylko, że nie zostało uwieńczone pomyślnym skutkiem, ale likwiduje się ze stratą. Bank nagle podwyższa stopę procentową, utrudnia nabywanie nowych pieniędzy; podwyższenie zaś stopy procentowej jest nowym alarmem na giełdzie" (Dunajewski, 2012, s. 144).

Można podejrzewać, że według Dunajewskiego, chociaż tego nie napisał wprost w swoich wykładach, stopa procentowa rośnie $\mathrm{z}$ dwóch powodów: nadmiernej ekspozycji na ryzyko oraz wzrostu popytu na kredyt.

Banki muszą szacować, jak wysokie rezerwy powinny utrzymywać. Dodatkowo na wysokość stopy procentowej wpływa ryzykowność projektu inwestycyjnego, jego potencjalna zyskowność, która sprawia, że przedsiębiorca jest gotów zaproponować zapłatę większego procentu (Dunajewski, 2012, s. 177) oraz popyt i podaż kapitału. We wcześniej przytaczanym fragmencie Dunajewski (2012, s. 143) zwraca uwagę na to, że bank emitując dodatkowe banknoty poprzez kredyt, nie opiera tego kredytu na kapitale - „nie dał więc bank kapitału, a jedynie zaufanie". W związku z tym bank musiał na siebie przyjąć większe ryzyko. Jednocześnie spada stopa procentowa, czyli wzrost ryzyka nie został wliczony w stopę procentową. W końcu jednak wybuch kryzys i banki podnoszą stopy, gdy kolejne przedsięwzięcia okazują się nierentowne (Dunajewski, 2012, s. 144). W tym momencie ujawnia się nadmierne ryzyko, na jakie wyeksponował się bank, zmuszające go teraz do ograniczenia ekspansji kredytowej i podniesienia stóp procentowych. 
Wyłożona przez Dunajewskiego teoria cykli ma pewne elementy wspólne z późniejszą teorią cyklu koniunkturalnego sformułowaną przez przedstawicieli szkoły austriackiej. Dunajewski, podobnie jak ekonomiści szkoły austriackiej, zwracał uwagę na istotność oszczędności w procesie akumulacji kapitału. Twierdził, że to oszczędności są podstawą akumulacji kapitału, a osoba dostarczająca oszczędności domaga się pewnego wynagrodzenia. Jeśli stopa procentowa będzie zbyt niska, to ludzie będą oszczędzać mniej, a być może nawet wcale. Na skutek tego spowolnieniu ulegnie akumulacja kapitału, która jest niezbędna dla rozwoju gospodarczego. Natomiast sam pieniądz bankowy nie może być utożsamiany z oszczędnościami. Dunajewski pisze, że to bank „daje tylko zaufanie” (Dunajewski 2012, s. 143). Istotność oszczędności podkreśla również szkoła austriacka. Jej reprezentanci piszą, że bank tworzy iluzję większej ilości oszczędności, emitując pieniądz bez pokrycia (Hayek, 2014; Mises, 2012). Jednak udzielając tego kredytu przedsiębiorcom, bank tworzy iluzję oszczędności. Zarówno więc w przypadku Dunajewskiego, jak i szkoły austriackiej, zwraca się uwagę na to, że kreacja pieniądza nie tworzy dodatkowych realnych oszczędności.

Podobnie jak Dunajewski, ekonomiści szkoły austriackiej twierdzą, że to nadmierna emisja pieniądza prowadzi do cyklu koniunkturalnego (Hayek, 2014; Mises, 2012), a głównym problemem są nierentowne inwestycje, których upadek będzie bolesny dla całej gospodarki (Roche, 2016). Według szkoły austriackiej kreacja kredytu przez sektor bankowy prowadzi do zaniżenia stopy procentowej poniżej jej naturalnego poziomu, którą wyznacza popyt na oszczędności i ich podaż. Nowy pieniądz trafia najpierw do rąk przedsiębiorców, którzy teraz dysponują dodatkową siłą nabywczą i zaczynają konkurować o zasoby. Ta dodatkowa siła nabywcza oraz zaniżona stopa procentowa tworzy iluzję zwiększonej ilości oszczędności w gospodarce. $\mathrm{Z}$ tego powodu przedsiębiorcy rozpoczynają inwestycje, które są niemożliwe do utrzymania i ostatecznie będą musiały być zlikwidowane (Hayek, 2014; Mises, 2012). Przedstawiciele szkoły austriackej, podobnie jak Dunajewski, zwracają uwagę, że nadmierna emisja pieniądza przez sektor bankowy jest przyczyną cyklu koniunkturalnego. Podkreślają oni również rolę błędnych inwestycji, czyli złego doboru projektów inwestycyjnych przez przedsiębiorców.

Kolejnym podobieństwem między teoriami kryzysu przedstawionymi przez szkołę austriacką i przez Dunajewskiego jest zwrócenie uwagi na to, kto otrzymuje kredyt. We fragmencie tekstu autorstwa Dunajewskiego, dotyczącym kryzysów, można dostrzec intuicję, która przypomina teorię Evansa i Baxendale'a (2008). Stwierdza on, podobnie jak wiele lat później Evans i Baxendale (2008) 
oraz Engelhardt (2012), że to dodatkowy kredyt bankowy umożliwia pozyskanie finansowania pewnym dodatkowym przedsiębiorcom (marginalnym przedsiębiorcom), którzy nie otrzymaliby kredytu, gdyby stopa procentowa nie była zaniżona (Dunajewski, 2012, s. 144). Evans i Baxendale (2008) oraz Engelhardt (2012) wskazują na różnice w zdolnościach prowadzenia biznesu między przedsiębiorcami - są przedsiębiorcy potrafiący lepiej prowadzić firmę. Ci lepsi przedsiębiorcy nie dają się zwieść błędnym sygnałom wysyłanym przez banki komercyjne, które zaniżają stopę procentową; mylą się przede wszystkim krańcowi, gorsi przedsiębiorcy. Zarówno w przypadku Dunajewskiego, jak i Austriaków to marginalny przedsiębiorca i jego przedsięwzięcia są tymi, które ostatecznie zostaną wyeliminowane przez kryzys i odpowiadają za nadmierny boom gospodarczy.

\section{Wartość pieniądza i tragedia wspólnego pastwiska}

Drugą po cyklu koniunkturalnym negatywną konsekwencją wolnej bankowości, według Dunajewskiego, jest spadek wartości pieniądza². Tej konsekwencji poświęca on mniej miejsca niż omówieniu cyklu koniunkturalnego.

Podobnie jak w przypadku emisji banknotów przez państwo, tak i emisja banknotów przez banki może negatywnie wpłynąć na wartość pieniądza. Banknoty emitowane przez banki komercyjne, mimo że są instrumentem dłużnym, funkcjonują de facto jako pieniądze. Innymi słowy, są doskonałymi lub niemal doskonałymi substytutami pieniądza. Ich powszechna akceptowalność wynika z konkurencji między firmami; przedsiębiorcy przyjmą w ramach zapłaty banknoty, aby nie stracić klienta (Dunajewski, 2012, s. 145).

Ta powszechna akceptacja banknotów w połączeniu ze skłonnością banków do nadmiernej emisji banknotów w systemie wolnej bankowości prowadzi do inflacji, która negatywnie wpływa na wartość majątku oraz aktywność gospodarczą. „Wszelka nasza własność materialna, wszelkie nasze dochody ostatecznie zależą od ceny; cenę wyrażamy w pewnej ilości środków obiegowych (...). cóż nam z tego, że grunt lub dom został naszym, jeżeli wartość jego wyceniona w złocie spadnie na skutek nadmiernego mnożenia znaków pieniężnych. Zachwiana jest własność, zachwiany tym samym kredyt i przemysł narodowy, bo

2 Dunajewski zwraca również uwagę na rolę przepływu kruszcu monetarnego pod wpływem emisji banknotów, pisząc, że „,bilet bankowy w zbyt wielkiej ilości (...) może kraj pozbawić pewnej ilości kruszców szlachetnych" (Dunajewski, 2012, s. 146). Niestety poza tym jednym zdaniem nie ma innego źródła, z którego można by dowiedzieć się czegoś więcej o jego poglądach na ten temat. Prawdopodobnie odnosi się do zarysowanego przez Davida Ricardo mechanizmu odpływu złota z kraju na skutek nadmiernej emisji banknotów (Grubel, 1961). 
któż będzie się trudnił przemysłem, jeżeli nie wie, czy środki obiegowe spadną, czy podniosą się na wartości” (Dunajewski, 2012, s. 146). Niepewność odnośnie do wartości pieniądza ma prowadzić z czasem do osłabienia dostępności kredytu oraz aktywności gospodarczej. Można podejrzewać, że Dunajewski ma tutaj na myśli zarówno spadek realnych zysków, jak i wzrost stóp procentowych z powodu inflacji.

Banknoty tracą również na wartości z tego powodu, że nadmierna emisja przez banki komercyjne prowadzi do sytuacji, w której banki nie są w stanie wypłacić wszystkim posiadaczom banknotów złota na żądanie. W trakcie kryzysu, gdy ludzie chcieli wypłacać złoto, ponieważ banki zaczynały mieć problemy finansowe, dochodziło do sytuacji spadku wartości banknotów danego banku, ponieważ ryzyko niewypłacalności banku sprawiało, że ludzie zaczynali wyceniać banknoty banku poniżej ich wartości nominalnej (Dunajewski, 2012, s. 144).

Wolna bankowość, czyli brak regulacji emisji banknotów przez banki komercyjne według terminologii Dunajewskiego prowadzi do sytuacji, którą współcześnie określa się mianem tragedii wspólnego pastwiska (Hardin, 2009). Jak pisze Dunajewski, powołując się na Sismondiego: „Interes cząstkowy każdego jest zbyt mały, aby go mógł zniewolić do poświęcania środków celem uchylenia niedogodności" (Dunajewski, 2012, s. 146).

Tragedia wspólnego pastwiska to sytuacja, gdy maksymalizujące swój zysk lub użyteczność podmioty korzystają z zasobów dostępnych bez ograniczeń dla wszystkich. Nikt nie ma prawa lub możliwości wykluczyć inne podmioty z korzystania $\mathrm{z}$ tych zasobów. W takiej sytuacji nie ma bodźców dla podmiotów do tego, by dbały o zasób - ograniczały swoje wykorzystanie lub inwestowały w jego odnawianie. Podmioty, które zdecydują się na ograniczenie wykorzystania zasobu lub inwestowanie w ten zasób, stracą, ponieważ większa ilość zasobów będzie dostępna dla konkurencji, która skorzysta z okazji. W związku z tym każdy podmiot będzie dążył do największego możliwego wykorzystania wspólnego zasobu i nie będzie mieć bodźców do dbania o zasób. W tym przypadku zasobem, który niszczą banki, jest pieniądz. Chociaż w tym przypadku nie mamy do czynienia $\mathrm{z}$ pewnym skończonym zasobem naturalnym i jego dewastacją, to wciąż konkurencja między bankami, według Dunajewskiego, ma szkodliwe skutki.

Banki komercyjne posiadające możliwość emisji banknotów będą udzielać kredytu w formie banknotów i obniżać nadmiernie stopy procentowe w gospodarce. Banki nie mają bodźców do ograniczania swojej ekspansji - jeśli one nie wyemitują dodatkowego kredytu po niższej stopie, to jedynie stracą klienta, który ten kredyt otrzyma w innym banku. Natomiast bank, który ograniczy swoją kreację kredytu, straci z powodu inflacji i zaniżenia stóp procentowych przez inne banki (Huerta de Soto, 1995). Chociaż Dunajewski nie omawia wprost 
struktury bodźców, to można się domyślić, że dostrzega ten problem, pisząc: „Bank, robią trudności, straciłby klienta” (Dunajewski, 2012, s. 145). Wcześniej w artykule zwrócono już uwagę, że konkurencja między bankami będzie prowadzić według Dunajewskiego do zaniżenia stopy procentowej (Dunajewski, 2012, s. 143), a inflacja dotyka majątku i zysku wszystkich podmiotów w gospodarce.

$\mathrm{Z}$ tego powodu Dunajewski stwierdza, że wolna bankowość nie jest optymalnym modelem sektora bankowego i „emisja biletów bankowych nie powinna być dozwolona wszystkim, tylko z pewnymi ostrożnościami, pod ścisłym dozorem władzy”, gdyż „tu również idzie o towar, którego dowolny obrót może wywołać szkodę" (Dunajewski, 2012, s. 146).

\section{Wnioski}

Analiza wykładu Dunajewskiego o bankowości pokazuje, że poglądy tego ekonomisty na bankowość, chociaż niezbyt obszernie wyłożone, były wartościowe i zawierają twierdzenia oraz myśli, które stały się kluczowe dla późniejszych teorii ekonomicznych. W sformułowanej przez niego teorii cyklu uznał on kreację kredytu za przyczynę cykli koniunkturalnych i zwrócił uwagę na problem błędnych inwestycji i marginalnych przedsiębiorców - można powiedzieć, że pod tym względem wyprzedził o wiele lat późniejszych ekonomistów szkoły austriackiej.

Pomimo swoich liberalnych poglądów potrafił on krytycznie spojrzeć na system oparty na konkurencji i dostrzec, że pewne praktyki biznesowe powinny być kontrolowane, ponieważ mogą być szkodliwe dla gospodarki. Za taką właśnie szkodliwą praktykę uznał emisję banknotów przez banki komercyjne, których działania mogą wywołać cykle i inflację. $Z$ tego powodu Dunajewski zalecał regulację w formie kontroli emisji banknotów przez sektor bankowy.

Przemyslaw Rapka - doktorant Uniwersytetu Ekonomicznego w Katowicach (ekonomia i finanse)

\section{Spis literatury}

Dunajewski, J. (2012). Wyklad ekonomii politycznej. Warszawa: Prohibita.

Dowd, K. (1993). Laissez-faire banking. London: Routledge.

Dowd, K. (1996). The case for financial laissez-faire. The Economic Journal, 106(436), 679-687. 
Engelhardt, L. (2012). Expansionary monetary policy and decreasing entrepreneurial quality. Quarterly Journal of Austrian Economics, 15(2), 172-194.

Evans, A. J., \& Baxendale, T. (2008). Austrian business cycle theory in light of rational expectations: The role of heterogenity, the monetary footprint and adverse selection in monetary expansion. Quarterly Journal of Austrian Economics, 11(2), 81-93.

Glasner, D. (1989). Free Banking and Monetary Reform. Cambridge: Cambridge University Press.

Grubel, H. G. (1961). Ricardo and Thornton on the transfer mechanism. The Quarterly Journal of Economics, 75(2), 292-301.

Harding, G. (2009). The tragedy of commons. Journal of Natural Resources Policy Research, 1(3), 243-253.

Hayek, F. A. von. (2014). Ceny i produkcja. W: A. Szymanowska, W. Falkowski (red.), Pieniądz i Kryzysy. Dzieła Zebrane. Tom I (s. 153-266). Wrocław: Instytut Ludwiga von Misesa.

Huerta de Soto, J. (1995). A critical analysis of central banks and fractional-reserve free banking from the Austrian school perspective. The Review of Austrian Economics, $8(2), 25-38$.

Koniarek, D. (2014). Julian Dunajewski (1821-1907), ekonomista i najlepszy minister skarbu c.k. monarchii. Instytut Misesa. Pobrano z: https://mises.pl/blog/2014/11/ 18/koniarek-julian-dunajewski-1821-1907-ekonomista-najlepszy-minister-skarbu-c-kmonarchii/ (dostęp: 24.07.2021).

Mises, L. von. (2012). Teoria pieniadza i kredytu. Warszawa: Fijorr Publishing.

Olejnik, T. (2017). Julian Dunajewski jako polityk. Acta Universitatis Lodziensis. Folia Historica, 98, 85-100.

Roche, G. A. G. (2016). Entrepreneurial ignition of business cycle: The corporate finance of malinvestment. The Review of Austrian Economics, 29(3), 253-276.

Sechrest, L. (2008). Free banking. theory, history and a laissez-faire model. Ludwig von Mises Institute.

Selgin, G. (1989). The theory of free banking. Lanham: Rowan \& Littlefield Publishers.

Selgin, G. (2017). Financial stability without central banks. London: Institute of Economic Affairs.

Szulczewski, G. (2019). Spuścizna intelektualna galicyjskich profesorów Uniwersytetu Jagiellońskiego w twórczości Adama Heydla. Galicja. Studia i materiały, 5, 290-307.

\section{Banking in the lectures of Julian Dunajewski}

Abstract: Julian Dunajewski was a Polish economist and Minister of the Treasury of Austria-Hungary in the second half of the XIX century. He also lectured at the Jagiellonian University in Cracow and at the University of Lviv. Unfortunately, he wrote little 
and his economic thought is known mainly from scripts from the 1870s. These include a discussion of the functioning of banks and the banking sector, as well as Dunajewski's thoughts on the economic consequences of an unregulated banking sector, where banks are free to issue banknotes. The text presents and analyses Julian Dunajewski's views on the functioning of the banking sector and the consequences of unregulated bank money creation. Dunajewski argued that the unregulated creation of money by commercial banks is the cause of business cycles and the decline in the value of money. His views on free banking were compared with the views of contemporary free banking advocates and economists of the Austrian school. The comparative analysis shows the similarities between the views of economists of the Austrian school and Julian Dunajewski on the consequences of money emission by commercial banks. According to both the Austrian school and Dunajewski, excessive bank credit is responsible for business cycles and the granting of credit to the wrong entrepreneurs.

Keywords: Julian Dunajewski, free banking, Polish economic thought, Austrian school of economic.

JEL Classification: B19, B26, G21. 